\title{
Perioperative insulin therapy
}

\author{
Prangmalee Leurcharusmee, ${ }^{1, *}$, Guy Kositratna ${ }^{2}$, De Q. Tran 3 , Thomas Schricker
}

\begin{abstract}
Surgical patients commonly develop hyperglycemia secondary to the neuroendocrine stress response. Insulin treatment of hyperglycemia is required to overcome the perioperative catabolic state and acute insulin resistance. Besides its metabolic actions on glucose metabolism, insulin also displays nonmetabolic physiological effects. Preoperative glycemic assessment, maintenance of normoglycemia, and avoidance of glucose variability are paramount to optimize surgical outcomes. This review discusses the basic physiology and effects of insulin as well as practical issues pertaining to its management during the perioperative period.
\end{abstract}

Keywords: blood glucose, diabetes mellitus, hyperglycemia, insulins, perioperative care

Hyperglycemia is associated with adverse outcomes in surgical and critically ill patients. Unfortunately, perioperative physicians often underestimate the neuroendocrine stress response in surgical patients and, as a result, overlook the importance of blood glucose management. Insulin constitutes the most reliable hypoglycemic agent for the perioperative period. This review provides an overview of the basic physiology and effects of insulin as well as practical issues pertaining to its perioperative use.

\section{Physiology of insulin: synthesis and secretion}

Insulin is a peptide hormone synthetized and secreted by $\beta$-cells of pancreatic islets of Langerhans. It promotes glucose homeostasis by facilitating cellular glucose uptake and by regulating carbohydrate, lipid, and protein metabolism.
Initially, synthetized as preproinsulin, the prohormone is first processed to proinsulin and subsequently converted to insulin and C-peptide, which are both stored in secretory granules and released into the circulation in equimolar amounts $[1,2]$.

Secretion of insulin is controlled by both nutrient and nonnutrient factors $[1,3]$. Inside $\beta$-cells, glucokinase phosphorylates glucose to glucose-6-phosphate, thereby generating a significant amount of adenosine triphosphate (ATP). Consequently, closure of $\mathrm{K}^{+}$-ATP-dependent channels, membrane depolarization, opening of voltage-dependent calcium channels, and exocytosis of insulin-containing granules occur. The uptake of cationic amino acids, $\mathrm{L}$-arginine and L-ornithine, into the $\beta$-cells results in membrane depolarization, thereby causing activation of voltagedependent calcium channels and enhancing insulin release. Other mechanisms of insulin secretion are regulated by non-nutrient mediators. Peptide hormones such as vasoactive intestinal peptide (VIP), glucose-dependent insulinotropic polypeptide (GIP), and glucagon-like peptide-1 (GLP-1) activate adenylyl

\footnotetext{
*Correspondence to: Prangmalee Leurcharusmee, Department of Anesthesiology, Maharaj Nakorn Chiang Mai Hospital, Chiang Mai University, Chiang Mai 50200, Thailand, e-mail: prangmalee.l@cmu.ac.th 'Department of Anesthesiology, Maharaj Nakorn Chiang Mai Hospital, Chiang Mai University, Chiang Mai 50200, Thailand 2Department of Anesthesiology, UF Health, University of Florida College of Medicine, Gainesville, FL 32209, USA

${ }^{3}$ Department of Anesthesia, Montreal General Hospital, McGill University, Montréal, QC H3G 1A4, Canada ${ }^{4}$ Department of Anesthesia, Royal Victoria Hospital, McGill University, Montréal, QC H4A 3J1, Canada ¿ Open Access. @ 2017 Prangmalee Leurcharusmee et al., published by Sciendo. (c) EY-NC-ND This work is licensed under the Creative Commons Attribution NonCommercial-NoDerivatives 4.0 License.
} 
cyclase activity and protein kinase A. In the cholinergic pathway, acetylcholine stimulates phospholipases and protein kinase $\mathrm{C}$.

Inhibition of insulin release is mediated by several mediators such as somatostatin, galanin, prostaglandins, and catecholamines (through the $\alpha 2$-adrenergic pathway) and involves activation of $\mathrm{G}$ proteins $[3,4]$.

Pancreatic $\beta$-cells secrete approximately $0.4-1.0$ international units (IU) of insulin $/ \mathrm{kg} /$ day in healthy adults and $0.5-0.7$ $\mathrm{IU} / \mathrm{kg} /$ day in patients with insulin-sensitive diabetes $[5,6]$. The basal insulin secretion accounts for approximately 50\% of the total daily insulin production [7]. Thus, the basal rates of insulin secretion range from 0.4 to $0.7 \mathrm{IU} / \mathrm{h}$ [8]. These rates are sufficient for insulin-dependent cellular uptake of glucose and the maintenance of normal fasting blood glucose levels by limiting gluconeogenesis and preventing uncontrolled hydrolysis of triglycerides.

\section{Actions of insulin}

Insulin plays an essential role in the transport of glucose into insulin-dependent cells such as myocytes and adipocytes. Insulin binds its receptors and thereby activates tyrosine kinase activity and phosphorylation of insulin-responsive substrates (IRSs). In turn, the phosphorylated IRS proteins bind to signaling molecules, such as phosphatidylinositol-3 kinase (PI-3 kinase). The latter promotes translation of glucose transporters (GLUTs) to the cell membrane resulting in antilipolysis and synthesis of glycogen, lipid, and protein [3, 8-10].

Anti-inflammatory, antioxidant, antithrombotic, antiatherosclerotic [11], and antiapoptotic effects of insulin have been documented [12-14]. Insulin produces its nonmetabolic action by binding to insulin receptors in endothelial cells, platelet, lymphocytes, macrophages, and monocytes. Inside vascular endothelial cells and platelets, insulin stimulates nitric oxide synthase and enhances nitric oxide production via the PI-3 kinase pathway, thereby causing vasodilation and inhibiting platelet aggregation. Through the mitogen-activated protein kinase (MAPK) pathway, insulin can also suppress several proinflammatory transcription factors and decrease the expression of endotoxin-mediated inflammatory mediators [15].

\section{Insulin therapy}

Human insulin and insulin analogs can be used to manage hyperglycemia. Structurally, synthetic human insulin is identical to its natural endogenous counterpart. Insulin analogs have been developed by modifying the amino acid sequence of the insulin molecule. Differences between human insulin and insulin analogs are inconsequential for the management of type 1 and type 2 diabetes as well as diabetic ketoacidosis (DKA) [16, 17].

Insulins are classified according to their pharmacokinetic profiles (Table 1). Long-acting analogs are commonly used as basal agents to mimic endogenous insulin, which is physiologically secreted to control blood glucose levels during periods of fasting. By contrast, rapid- and short-acting preparations are intermittently administered to prevent or treat postprandial and stress-induced hyperglycemia. Alternately, continuous subcutaneous and intravenous infusions of rapid- and shortacting insulin also provide a basal insulin regimen; moreover, they can be adjusted in response to a specific blood glucose concentration.

Table 1. Pharmacokinetics, role of treatment, and dosing of insulin preparations [18-21]

\begin{tabular}{|c|c|c|c|c|c|}
\hline Insulin type & Onset & Peak & Effective duration & Role of treatment & Dosing \\
\hline Rapid acting & $5-15 \min$ & $30-90 \mathrm{~min}$ & $2-5 \mathrm{~h}$ & Bolus & Postprandial \\
\hline Aspart (NovoRapid) & $5-15 \min$ & $30-90 \mathrm{~min}$ & $2-5 \mathrm{~h}$ & Bolus & Postprandial \\
\hline \multicolumn{6}{|l|}{ Lispro (Humalog) } \\
\hline Short acting & $30-60 \mathrm{~min}$ & $2-3 h$ & $5-8 h$ & Bolus & Postprandial \\
\hline \multicolumn{6}{|l|}{ Regular (Humulin R) } \\
\hline Intermediate acting & $1-2 h$ & $4-10 h$ & $10-16 \mathrm{~h}$ & Basal & Twice daily \\
\hline NPH (Humulin N) & $1-2 \mathrm{~h}$ & $4-12 h$ & $12-18 h$ & Basal & Twice daily \\
\hline \multicolumn{6}{|l|}{ Lente (Monotard) } \\
\hline Long acting & $2-3 h$ & $4-8 \mathrm{~h}$ & $8-24 \mathrm{~h}$ & Basal & Twice daily \\
\hline Ultralente (Humulin U) & $2-4 \mathrm{~h}$ & No peak & $20-24 \mathrm{~h}$ & Basal & Once daily \\
\hline Glargine (Lantus) & $3-4 h$ & $6-8 \mathrm{~h}$ & Up to $20-24 \mathrm{~h}$ & Basal & Once/twice daily \\
\hline Detemir (Levemir) & $30-90 \mathrm{~min}$ & No peak & Up to $42 \mathrm{~h}$ & Basal & Once daily \\
\hline Degludec & & & & & \\
\hline
\end{tabular}




\section{Route of delivery}

Endogenous insulin is released from pancreatic $\beta$-cells into the portal venous system; subsequently, approximately $60 \%$ undergoes hepatic extraction. Therefore, the insulin concentration in the portal veins can be 3 times higher than that in the peripheral circulation. When exogenous insulin is parenterally administered, it distributes throughout the circulation thus resulting in a high level peripherally, but a low concentration in the liver [23]. This relative insulin deficiency in the portal circulation attenuates hepatic glycogenolysis and gluconeogenesis during fasting and compromises suppression of glucagon secretion in the fed state.

Subcutaneous administration of rapid-acting insulin has been shown to provide similar glycemic control as intravenous infusion of regular insulin [24-26]. The accumulation of repeated doses of subcutaneous insulin can be a concern: therefore, additional doses should not be administered until after the time-to-peak effect [27]. Although the subcutaneous basal-bolus insulin regimen constitutes the preferred method for maintaining target glycemia in hospitalized, noncritically ill patients, the American Association of Clinical Endocrinologists/American College of Endocrinology (AACE/ACE) and American Diabetes Association (ADA) recommend the intravenous infusion of regular insulin in critically ill patients and those undergoing major surgical procedures [28, 29].

Regular insulin administered intravenously displays a faster onset and shorter duration of action compared with that given subcutaneously and intramuscularly [30,31]. A bolus dose of intravenous insulin lowers the blood glucose within minutes with the maximum effect occurring after 20-30 min. Because the plasmatic half-life of insulin is about 4-6 min and the hypoglycemic effect lasts only about $1 \mathrm{~h}$, a continuous intravenous infusion is required to maintain a basal insulin level [32].

\section{Perioperative insulin dosing}

The effective dose of insulin depends on the extent of the patient's insulin resistance and the target blood glucose. Insulin sensitivity is reflected by the patient's total daily dose and is predicted by plasma HbAlc level [33]. Target blood glucose levels are listed in diabetes management guidelines disseminated by various organizations (Table 2).

For a basal-bolus insulin regimen, the calculated total daily dose of insulin ranges between 0.2 and $0.5 \mathrm{IU} / \mathrm{kg}$ based on the patient's age, renal function, and blood glucose concentration [34]. This calculated dose is equally partitioned into basal and prandial components [7].
Table 2. Recommendations for glycemic control during perioperative period

\begin{tabular}{|c|c|c|}
\hline & Perioperative care & Intensive care \\
\hline ADA (2017) [28] & $80-180 \mathrm{mg} / \mathrm{dL}$ & $\begin{array}{l}140-180 \mathrm{mg} / \mathrm{dL} \text { with } \\
\text { insulin therapy, generally } \\
<180 \mathrm{mg} / \mathrm{dL}\end{array}$ \\
\hline AACE/ACE (2015) [29] & $\begin{array}{l}<140 \mathrm{mg} / \mathrm{dL} \text { for } \\
\text { premeal glucose } \\
<180 \mathrm{mg} / \mathrm{dL} \text { for } \\
\text { random glucose }\end{array}$ & $140-180 \mathrm{mg} / \mathrm{dL}$ \\
\hline AAGBI (2015) [38] & $108-180 \mathrm{mg} / \mathrm{dL}$ & Not available \\
\hline CDA (2013) [73] & $\begin{array}{l}90-144 \mathrm{mg} / \mathrm{dL} \text { for } \\
\text { premeal glucose } \\
<180 \mathrm{mg} / \mathrm{dL} \text { for } \\
\text { random glucose }\end{array}$ & $144-180 \mathrm{mg} / \mathrm{dL}$ \\
\hline JBDS (2012) [74] & $\begin{array}{l}108-180 \mathrm{mg} / \mathrm{dL} \\
72-216 \mathrm{mg} / \mathrm{dL} \text { is } \\
\text { acceptable }\end{array}$ & Not available \\
\hline SAMBA (2010) [27] & $\begin{array}{l}90-130 \mathrm{mg} / \mathrm{dL} \text { for } \\
\text { premeal glucose } \\
<180 \mathrm{mg} / \mathrm{dL} \text { for } \\
\text { random glucose }\end{array}$ & Not available \\
\hline
\end{tabular}

AACE/ACE, The American Association of Clinical Endocrinologists/ American College of Endocrinology; AAGBI, The Association of Anaesthetists of Great Britain \& Ireland; ADA, The American Diabetes Association; CDA, The Canadian Diabetes Association; JBDS, The Joint British Diabetes Society; SAMBA, The Society of Ambulatory Anesthesia

For supplemental insulin, the initial bolus dose of regular insulin ranges between 2 and 10 IU [34] or is based on the "rule of 1500 " for surgical patients. The latter strategy divides 1500 by the total daily insulin dose. The result predicts the expected decrease in glycemia with 1 unit of insulin [27].

For continuous regimens, the insulin starts at $1-2 \mathrm{IU} / \mathrm{h}$, which mimics basal endogenous secretion [3]. Insulin is administered simultaneously with a continuous infusion of dextrose ( $2 \mathrm{~g} / \mathrm{kg} / \mathrm{day})$ [35-37]. Blood glucose should be checked before the infusion and monitored hourly (or more frequently if the results fall out of the target range) [38]. Both insulin and dextrose rates are titrated to maintain normoglycemia and reduce glycemic variability.

Insulin is considered 1 of the top 5 high-alert medications [39]. Errors in insulin prescribing and administration can be high because of the prevalence of insulin use and its narrow therapeutic index. Insulin orders written with abbreviations such as "u", "iu", and "U" have been misinterpreted as " 0 " or " 10 " and have caused from 10 to 100 times dosing errors [40]. Preparation of insulin with normal syringes potentially generates confusion and results in 10 -fold overdose errors [41]. Thus, only insulin syringes should be employed. 


\section{Perioperative benefits of insulin}

Surgery, anesthesia, acute illness, and fasting constitute stressors, which lead to metabolic perturbation. Perioperative hyperglycemia is associated with the stress-induced release of counter-regulatory hormones and proinflammatory cytokines, which, in turn, result in increased endogenous glucose production [42] and a state of impaired insulin sensitivity. This transient insulin resistance, the so-called "diabetes of injury" [43], is most pronounced on the first postoperative day and may persist for days or weeks after surgery depending on the anatomic location and invasiveness of the intervention [44, 45]. These metabolic derangements contribute to hyperglycemia in both diabetic and nondiabetic patients. Significant amounts of insulin are required to overcome this state of insulin resistance and hyperglycemia. Concurrent administration of high doses of insulin together with dextrose to achieve normoglycemia provides significant benefits stemming from insulin's metabolic and nonmetabolic properties $[36,46]$.

The cardioprotective effect of insulin can improve clinical outcomes for patients undergoing cardiac surgery. For instance, perioperative insulin administration, coupled with glucose and insulin administration while maintaining normoglycemia (i.e., the GIN therapy), and the glucoseinsulin-potassium (GIK) concept have been shown to improve left ventricular function in coronary artery bypass graft (CABG) surgery [47, 48], attenuate the degree of myocardial injury in off-pump coronary artery bypass (OPCAB) surgery [49], reduce the incidence of low cardiac output state, and the need for inotropic support in patients with aortic stenosis undergoing aortic valve replacement [50] as well as prevent myocardial oxidative stress in patients with acute coronary syndrome who are undergoing percutaneous coronary intervention [51].

Hyperglycemic crises, DKA, and hyperosmolar hyperglycemia are precipitated by surgical stress, fasting, and inadequate or discontinued insulin therapy. Blood or urine ketone levels should be measured to differentiate these conditions. Insulin administration is essential for the treatment of hyperglycemic crises, because it promotes glucose utilization, diminishes glycogenolysis as well as gluconeogenesis, and suppresses ketogenesis. Intravenous infusion remains the preferred route of insulin delivery for patients with DKA [52].

\section{Perioperative risks of insulin}

Hypoglycemia represents one of the most common complications in surgical and critically ill patients. Blood glucose levels below $65-70 \mathrm{mg} / \mathrm{dL}$ usually serve as a threshold for activation of glucagon and epinephrine secretion. Symptoms of hypoglycemia are predominantly neurological and adrenergic in nature: they include sweating, tachycardia, tremors, convulsion, and coma. Tight glycemic control can lead to hypoglycemia desensitization and reduced recognition of symptoms, thus risking an even more pronounced drop in blood glucose [53]. Expectedly, most clinical symptoms are masked during anesthesia and can be blunted by postoperative sedation. Therefore, blood glucose should be regularly monitored during the perioperative period.

Several electrolytic disorders (e.g., hypokalemia, hypophosphatemia, and hypomagnesemia) are associated with insulin therapy [54]. The latter stimulates the $\mathrm{Na}^{+}-\mathrm{K}^{+}$-ATPase pump activity and subsequently redistributes potassium into intracellular compartment. Moreover, it promotes transport of both glucose and phosphate into skeletal muscle and hepatic cells. Hypokalemia, hypophosphatemia, and acidosis (in the setting of DKA) cause urinary loss of magnesium. Administration of insulin leads only to a slight decrease in serum levels of potassium, phosphate, and magnesium. However, severe depletion of potassium and phosphate can occur during the treatment of severe hyperglycemia [52].

\section{Assessment of insulin's effects}

Metabolic and nonmetabolic effects of insulin can be detected with clinical and laboratory evaluations (Table 3).

\section{Perioperative implications}

Robust literature from recent decades has repeatedly linked perioperative hyperglycemia to increased rates of complications and hospital mortality [55-58]. Conversely, studies in critically ill patients [59], cardiac surgery [60-61], and noncardiac surgery [56-58, 62-67] have demonstrated that improved glycemic control mitigates the risk of developing multiorgan failure, curtails systemic as well as wound infections, and reduces short- and long-term mortality.

Glucose variability (i.e., the fluctuation of glucose concentrations) has been suggested as an important predictor of morbidity and mortality after cardiac surgery [68], liver transplantation [69], and in critically ill patients [70, 71]. The increased risk of adverse outcomes associated with glucose fluctuation could be related to the activation of oxidative stress [72]. During the intraoperative period, one should expect glucose fluctuation to increase because of the stress-induced acute insulin resistance.

Unfortunately, to date, the optimal glucose level required for improved clinical outcomes remains unknown: hence, 
Table 3. Assessment points for effects of insulin

\begin{tabular}{|c|c|c|c|}
\hline \multirow[t]{2}{*}{ Effect } & \multirow[t]{2}{*}{ Potential case } & \multicolumn{2}{|c|}{ Assessment } \\
\hline & & Clinical & Investigation \\
\hline \multicolumn{4}{|l|}{ Metabolic effect } \\
\hline Glucose lowering & $\begin{array}{l}\text { Fasting } \\
\text { Use of oral hypoglycemic } \\
\text { Renal and hepatic impairment } \\
\text { Alcohol consumption }\end{array}$ & $\begin{array}{l}\text { Sweating } \\
\text { Tachycardia } \\
\text { Tremors } \\
\text { Convulsion } \\
\text { Coma }\end{array}$ & Blood glucose \\
\hline Hypokalemia & $\begin{array}{l}\text { Mineralocorticoid excess (Cushing syndrome, primary } \\
\text { hyperaldosteronism, use of corticosteroids) } \\
\text { Parenteral or enteral nutrition } \\
\text { Thiazide or loop diuretics use }\end{array}$ & $\begin{array}{l}\text { Fatigue } \\
\text { Weakness } \\
\text { Arrhythmia } \\
\text { Polyuria }\end{array}$ & $\begin{array}{l}\text { Serum/urine electrolytes } \\
\text { Electrocardiogram }\end{array}$ \\
\hline Hypophosphatemia & $\begin{array}{l}\text { Hyperparathyroidism } \\
\text { Parenteral or enteral nutrition }\end{array}$ & $\begin{array}{l}\text { Weakness (diplopia, dysphagia) } \\
\text { Confusion }\end{array}$ & Serum electrolyte \\
\hline Protein anabolism & - & - & $\begin{array}{l}\text { Serum albumin } \\
\text { Nitrogen balance }\end{array}$ \\
\hline Antilipolysis & - & - & $\begin{array}{l}\text { Serum-free fatty acids } \\
\text { Acid-base balance }\end{array}$ \\
\hline \multicolumn{4}{|l|}{ Cardiovascular effect } \\
\hline Vasodilation & Concomitant use of vasodilators & $\begin{array}{l}\text { Increased blood flow to skeletal, } \\
\text { myocardial, cerebral tissues }\end{array}$ & $\begin{array}{l}\text { Blood pressure } \\
\text { Vascular resistance }\end{array}$ \\
\hline Positive inotropic & - & - & Cardiac output \\
\hline
\end{tabular}

there exist various published guidelines for glycemic control in critically ill and surgical patients (Table 2).

\section{Preoperative period}

Preoperative hyperglycemia correlates with poor postoperative outcomes for diabetic and nondiabetic patients [75, 76]. Preoperative assessment and optimization of diabetes should therefore be focused to prevent such consequences. The prevalence of nondiabetic patients showing an increased preoperative fasting blood glucose is approximately $21 \%-25 \%[77,78]$. Indeed, undiagnosed diabetic patients show higher risks of perioperative morbidity and mortality than their known diabetic counterparts [62, 79-80].

Preoperative glycemic management depends on the type and duration of diabetes, the type of antidiabetic medications, the level of glycemic control, the duration of fasting, and the nature of the proposed surgical intervention.

In addition to being an indicator of blood glucose control during the previous 3-4 months [81], plasma glycated hemoglobin $\mathrm{A}(\mathrm{HbA} 1 \mathrm{c})$ constitutes an independent predictor of postoperative outcomes after major colorectal [82, 83], cardiac [84], and vascular surgery [85]. Moreover, the preoperative $\mathrm{HbAlc}$ levels help predict intraoperative insulin sensitivity [33] which, in turn, provides a marker for surgical stress with potential relevance for postoperative outcomes and recovery [86, 87].
A recommended HbA1c goal for adults is $<7 \%$ [28]. If the preoperative $\mathrm{HbAlc}$ exceeds $8.5 \%$, elective surgery may be delayed, and the diabetes specialist team should be consulted for preoperative optimization [38, 74]. Preoperative blood glucose and HbAlc levels should be verified in diabetic patients at the time of referral for surgery. However, unless clinical suspicion suggests otherwise, these tests are not recommended as routine screening for patients without documented diabetes [38, 88, 89].

Preoperative insulin therapy in well-controlled diabetic patients undergoing nonmajor surgery should simply be managed by modifying their usual diabetes medications $[27,38]$. Basal glycemic control with a daily dose of longacting insulin should be reduced by $20 \%$ on the day before the surgery. On the surgical day, blood glucose level must be checked and the long-acting background insulin should be continued at $80 \%$ of its usual dose even though intravenous insulin infusion is required. The rapid- and short-acting insulin used for prandial glycemic control must be held during the perioperative fasting period. For type 1 diabetic patients receiving subcutaneous insulin pump therapy, continuation of the basal infusion at $80-100 \%$ of the usual rate is recommended upon an initiation of fasting [90]. However, the accuracy of the basal rate must be assessed preoperatively by the diabetes specialist team.

Insulin-treated patients with suboptimal glycemic control or subjects scheduled for major elective surgery should be 
admitted 2-3 days before the surgery to optimize blood glucose levels and other diabetes-related conditions such as impaired cardiac function and electrolyte abnormalities [37]. Subcutaneous intermediate-acting insulin with preprandial shortor rapid-acting insulin is administered and titrated to obtain the daily insulin requirement [91]. During the perioperative period, continuous intravenous glucose-insulin infusions are recommended for basal and correctional therapy because of their titratability and predictable absorption [92]. For insulinnaïve and nondiabetic patients, perioperative insulin therapy may be considered if the blood glucose levels are significantly elevated [27].

\section{Intraoperative period}

Several strategies have been proposed to attenuate the stressinduced catabolic state and acute insulin resistance triggered by surgical tissue trauma. Combined administration of insulin and dextrose can be implemented intraoperatively [93]. The conventional "insulin sliding scale" provides a simple titration scheme to achieve a target glycemic range; despite its popularity, this strategy is reactive, as it attempts to treat hyperglycemic episodes after their occurrence. By contrast, a preemptive infusion of high-dose insulin with rate adjustment of dextrose to maintain targeted blood glucose levels will preserve normoglycemia during major abdominal [94] and cardiac surgery [95]. In addition, supraphysiological doses of insulin provide benefits derived from insulin's nonmetabolic properties [47, 96, 97].

During insulin therapy, blood glucose must be closely monitored. Generally, a blood gas analyzer and glucose meter are used to measure intraoperative glucose levels. The accuracy of capillary blood glucose analysis using glucose meters depends on several factors including hematocrit, blood pressure, temperature, $\mathrm{pH}$, anesthetic technique, medications, and glucose meter technology. With the newer technologies, the glucose meters provide acceptable accuracy for intraoperative subcutaneous insulin dosing, which lead to ameliorating of glycemic control efficacy [98, 99]. Moreover, improved control of glucose variability has been demonstrated after cardiac surgery when a continuous glucose monitoring was used $[100,101]$. However, the efficacy and reliability of continuous glucose monitoring during the perioperative period require further elucidation [28, 102].

Intraoperative hyper- and hypoglycemia must be avoided. In type 1 diabetic patients, the basal rate of insulin must be continued throughout surgery to prevent DKA. If glycemia exceeds $200 \mathrm{mg} / \mathrm{dL}$, ketone levels should be measured and the treatment of hyperglycemia should be implemented based on potential etiology and clinical and laboratory tests [28, 38]. Blood glucose levels $<70 \mathrm{mg} / \mathrm{dL}$ should be corrected with $15-20 \mathrm{~g}$ of glucose, and glycemia should be assessed $15 \mathrm{~min}$ after the implementation of treatment [28].

The judicious choice of intraoperative anesthetic technique can also help minimize the catabolic state seen in surgical patients. For instance, neuraxial blocks are reputed to blunt the neuroendocrine stress response and attenuate insulin resistance [103]. This facilitates glucose utilization and reduces protein loss and hyperglycemia.

\section{Postoperative period}

Oral intake should be restarted as soon as possible. In noncritically ill patients undergoing minor surgery, the preoperative subcutaneous insulin regimen may be reinstituted upon resuming enteral nutrition $[38,104]$. For ambulatory patients, subcutaneous rapid-acting insulin is preferred to its regular counterpart, because it will shorten the duration of observation for hypoglycemia postoperatively [27]. For patients undergoing major surgery with intraoperative use of insulin, the latter should be continued along with a dextrose infusion or parenteral nutrition during periods of uncertain alimentation. When the patient is able to tolerate a normal diet, the intravenous insulin infusion can be transitioned to a subcutaneous regimen. The subcutaneous insulin is started with the first meal and the intravenous insulin terminated shortly thereafter to ensure that baseline insulin requirements are always met (especially in type 1 diabetic patients) [91].

During the patient's hospital stay, postoperative stressinduced hyperglycemia should be treated with rapid- or shortacting insulin. The dose is calculated by dividing the daily insulin requirement by 30 for every $50 \mathrm{mg} / \mathrm{dL}$ above the glycemic goal [91]. The total dose of insulin and adequacy of oral intake should be reviewed on a daily basis. If carbohydrate intake is unreliable, the basal-bolus insulin regimen should be selected.

\section{Conclusion}

Perioperative metabolic perturbation and its adverse consequences result from the transient hypercatabolic state and insulin resistance, which are both induced by surgical stress. Awareness and appropriate metabolic intervention are key components of modern perioperative care. Adequate insulin and glucose administration should be provided to maintain normal blood glucose level and control its variability. 
Despite the existing evidence of benefits from metabolic effects of insulin, clinical evidence supporting its nonmetabolic properties remains lacking. Future research into the mechanism and potential benefits of insulin therapy in organ protection is required to understand more fully its therapeutic role during the perioperative period.

Author contributions. All the authors fulfilled all the International Committee of Medical Journal Editor criteria for authorship.

Acknowledgments. We did not receive any specific grant for this research from any funding agency in the public, commercial, or not-for-profit sectors.

Conflicts of interest statement. The authors have each completed and submitted an International Committee of Medical Journal Editors Uniform Disclosure Form for Potential Conflicts of Interest. None of the authors disclose any potential conflict of interest.

\section{References}

[1] Fu Z, Gilbert ER, Liu D. Regulation of insulin synthesis and secretion and pancreatic beta-cell dysfunction in diabetes. Curr Diabetes Rev. 2013; 9:25-53.

[2] Jones AG, Hattersley AT. The clinical utility of C-peptide measurement in the care of patients with diabetes. Diabet Med. 2013; 30:803-17.

[3] Wilcox G. Insulin and insulin resistance. Clin Biochem Rev. 2005; 26:19-39.

[4] Sharp GW. Mechanisms of inhibition of insulin release. Am J Physiol. 1996; 271:C1781-99.

[5] Korytkowski MT. In-patient management of diabetes: controversies and guidelines. Indian J Endocrinol Metab. 2013; 17:S630-5.

[6] Redmon B, Caccamo D, Flavin P, Michels R, O'Connor P, Roberts $\mathrm{J}$, et al. Inpatient diabetes management. In: Institute for Clinical Systems Improvement, editors. Diagnosis and management of type 2 diabetes mellitus in adults. 16th ed. [online]. 2014 [cited 2017 Sept 01]; Available from: https://www.ohcoop.org/wp-content/uploads/ Clinical-Guidelines-Type-2-Diabetes-in-Adults.pdf

[7] Polonsky KS, Given BD, Hirsch L, Shapiro ET, Tillil H, Beebe C, et al. Quantitative study of insulin secretion and clearance in normal and obese subjects. J Clin Invest. 1988; 81:435-41.

[8] Akhtar S, Barash PG, Inzucchi SE. Scientific principles and clinical implications of perioperative glucose regulation and control. Anesth Analg. 2010; 110:478-97.

[9] Dimitriadis G, Mitrou P, Lambadiari V, Maratou E, Raptis SA. Insulin effects in muscle and adipose tissue. Diabetes Res Clin Pract. 2011; 93:S52-9.

[10] Girard M, Schricker T. Perioperative glucose control: living in uncertain times-continuing professional development. Can J Anaesth. 2011; 58:312-20.
[11] Dandona P, Aljada A, Mohanty P, Ghanim H, Bandyopadhyay A, Chaudhuri A. Insulin suppresses plasma concentration of vascular endothelial growth factor and matrix metalloproteinase-9. Diabetes Care. 2003; 26:3310-4.

[12] Dandona P, Aljada A, Chaudhuri A, Mohanty P, Garg R. Metabolic syndrome: a comprehensive perspective based on interactions between obesity, diabetes, and inflammation. Circulation. 2005; 111:1448-54.

[13] Ng KW, Allen ML, Desai A, Macrae D, Pathan N. Cardioprotective effects of insulin: how intensive insulin therapy may benefit cardiac surgery patients. Circulation. 2012; 125:721-8.

[14] Chaudhuri A, Dandona P, Fonseca V. Cardiovascular benefits of exogenous insulin. J Clin Endocrinol Metab. 2012; 97:3079-91.

[15] Dandona P, Aljada A, Mohanty P, Ghanim H, Hamouda W, Assian $\mathrm{E}, \mathrm{Ahmad}$ S. Insulin inhibits intranuclear nuclear factor $\kappa \mathrm{B}$ and stimulates $\mathrm{I} \kappa \mathrm{B}$ in mononuclear cells in obese subjects: evidence for an anti-inflammatory effect? J Clin Endocrinol Metab. 2001; 86:3257-65.

[16] Singh SR, Ahmad F, Lal A, Yu C, Bai Z, Bennett H. Efficacy and safety of insulin analogues for the management of diabetes mellitus: a meta-analysis. Can Med Assoc J. 2009; 180:385-97.

[17] Umpierrez GE, Jones S, Smiley D, Mulligan P, Keyler T, Temponi A, et al. Insulin analogs versus human insulin in the treatment of patients with diabetic ketoacidosis: a randomized controlled trial. Diabetes Care. 2009; 32:1164-9.

[18] DeWitt DE, Hirsch IB. Outpatient insulin therapy in type 1 and type 2 diabetes mellitus: scientific review. JAMA. 2003; 289:2254-64.

[19] Owens DR. Insulin preparations with prolonged effect. Diabetes Technol Ther. 2011; 13:S5-14.

[20] Kalra S, Gupta Y. Clinical use of insulin degludec: practical experience and pragmatic suggestions. N Am J Med Sci. 2015; 7:81-5.

[21] Donner T. Insulin - pharmacology, therapeutic regimens and principles of intensive insulin therapy. In: De Groot LJ, Chrousos G, Dungan K, Feingold KR, Grossman A, Hershman JM, et al., editors. Endotext [online]. 2010 [cited 2017 Jan 10]. Available from: https:// www.ncbi.nlm.nih.gov/books/NBK278938/.

[22] Heise T, Pieber TR. Towards peakless, reproducible and long-acting insulins. An assessment of the basal analogues based on isoglycaemic clamp studies. Diabetes Obes Metab. 2007; 9:648-59.

[23] Matteucci E, Giampietro O, Covolan V, Giustarini D, Fanti P, Rossi R. Insulin administration: present strategies and future directions for a noninvasive (possibly more physiological) delivery. Drug Des Devel Ther. 2015; 9:3109-18.

[24] Umpierrez GE, Latif K, Stoever J, Cuervo R, Park L, Freire AX, Kitabchi AE. Efficacy of subcutaneous insulin lispro versus continuous intravenous regular insulin for the treatment of patients with diabetic ketoacidosis. Am J Med. 2004; 117:291-6.

[25] Vincent M, Nobecourt E. Treatment of diabetic ketoacidosis with subcutaneous insulin lispro: a review of the current evidence from clinical studies. Diabetes Metab. 2013; 39:299-305.

[26] Boullu-Sanchis S, Ortega F, Chabrier G, Busch MS, Uhl C, Pinget $\mathrm{M}$, Jeandidier N. Efficacy of short term continuous subcutaneous insulin lispro versus continuous intravenous regular insulin in poorly controlled, hospitalized, type 2 diabetic patients. Diabetes Metab. 2006; 32:350-7.

[27] Joshi GP, Chung F, Vann MA, Ahmad S, Gan TJ, Goulson DT, et al. Society for ambulatory anesthesia consensus statement on perioperative blood glucose management in diabetic patients undergoing ambulatory surgery. Anesth Analg. 2010; 111:1378-7. 
[28] The American Diabetes Association. Standards of medical care in diabetes-2017: summary of revisions. Diabetes Care. 2017; 40:S4-5.

[29] Handelsman Y, Bloomgarden ZT, Grunberger G, Umpierrez G, Zimmerman RS, Bailey TS, et al. American Association of Clinical Endocrinologists and American College of Endocrinology_clinical practice guidelines for developing a diabetes mellitus comprehensive care plan-2015-executive summary. Endocr Pract. 2015; 21:1-87.

[30] Owens DR, Jones MK, Hayes TM, Heding LG, Alberti KG, Home PD, Burrin JM. Comparative study of subcutaneous, intramuscular, and intravenous administration of human insulin. Lancet. 1981; 2:118-22.

[31] Guerra SM, Kitabchi AE. Comparison of the effectiveness of various routes of insulin injection: insulin levels and glucose response in normal subjects. J Clin Endocrinol Metab. 1976; 42:869-74.

[32] Evans CH, Lee J, Ruhlman MK. Optimal glucose management in the perioperative period. Surg Clin North Am. 2015; 95:337-54.

[33] Sato H, Carvalho G, Sato T, Lattermann R, Matsukawa T, Schricker $\mathrm{T}$. The association of preoperative glycemic control, intraoperative insulin sensitivity, and outcomes after cardiac surgery. J Clin Endocrinol Metab. 2010; 95:4338-44.

[34] Umpierrez GE, Hellman R, Korytkowski MT, Kosiborod M, Maynard GA, Montori VM, et al. Management of hyperglycemia in hospitalized patients in non-critical care setting: an Endocrine Society Clinical Practice Guideline. J Clin Endocrinol Metab. 2012; 97:16-38.

[35] Gosmanov AR, Umpierrez GE. Management of hyperglycemia during enteral and parenteral nutrition therapy. Curr Diab Rep. 2013; 13:155-62.

[36] Carvalho G, Lattermann R, Codere-Maruyama T, Schricker T. Glucose and insulin administration while maintaining normoglycemia: the GIN concept. Minerva Anestesiol. 2013; 79:74-82.

[37] Dagogo-Jack S, Alberti KGMM. Management of diabetes mellitus in surgical patients. Diabetes Spectr. 2002; 15:44-8.

[38] Association of Anaesthetists of Great Britain and Ireland, Working party members:, Barker P, Creasey PE, Dhatariya K, Levy N, et al. Peri-operative management of the surgical patient with diabetes 2015. Anaesthesia. 2015; 70:1427-40.

[39] Patient Safety Alert. 'High-alert' medications and patient safety. Int J Qual Health Care. 2001; 13:339-40.

[40] Koczmara C, Jelincic V, Dueck C. Dangerous abbreviations: "U" can make a difference. Dynamics. 2005; 16:11-5.

[41] Koczmara C, Hyland S, Jelincic V. High alert: preventing insulin errors. Dynamics. 2004; 15:10-1.

[42] Barth E, Albuszies G, Baumgart K, Matejovic M, Wachter U, Vogt J, et al. Glucose metabolism and catecholamines. Crit Care Med. 2007; 35:S508-18.

[43] Vanhorebeek I, Van den Berghe G. Diabetes of injury: novel insights. Endocrinol Metab Clin North Am. 2006; 35:859-72.

[44] Thorell A, Efendic S, Gutniak M, Haggmark T, Ljungqvist O. Development of postoperative insulin resistance is associated with the magnitude of operation. Eur J Surg. 1993; 159:593-9.

[45] Thorell A, Efendic S, Gutniak M, Haggmark T, Ljungqvist O. Insulin resistance after abdominal surgery. Br J Surg. 1994; 81:59-63.

[46] Ellger B, Debaveye Y, Vanhorebeek I, Langouche L, Giulietti A, Van Etten E, et al. Survival benefits of intensive insulin therapy in critical illness: impact of maintaining normoglycemia versus glycemiaindependent actions of insulin. Diabetes. 2006; 55:1096-105.
[47] Sato H, Hatzakorzian R, Carvalho G, Sato T, Lattermann R, Matsukawa T, Schricker T. High-dose insulin administration improves left ventricular function after coronary artery bypass graft surgery. J Cardiothorac Vasc Anesth. 2011; 25:1086-91.

[48] Albacker TB, Carvalho G, Schricker T, Lachapelle K. Myocardial protection during elective coronary artery bypass grafting using high-dose insulin therapy. Ann Thorac Surg. 2007; 84:1920-7.

[49] Shim JK, Yang SY, Yoo YC, Yoo KJ, Kwak YL. Myocardial protection by glucose-insulin-potassium in acute coronary syndrome patients undergoing urgent multivessel off-pump coronary artery bypass surgery. Br J Anaesth. 2013; 110:47-53.

[50] Howell NJ, Ashrafian H, Drury NE, Ranasinghe AM, Contractor H, Isackson $\mathrm{H}$, et al. Glucose-insulin-potassium reduces the incidence of low cardiac output episodes after aortic valve replacement for aortic stenosis in patients with left ventricular hypertrophy: results from the hypertrophy, insulin, glucose, and electrolytes (HINGE) trial. Circulation. 2011; 123:170-7.

[51] Demircan S, Yazici M, Diraman E, Demircan G, Kilicaslan F, Durna K, et al. The effect of glucose-insulin-potassium treatment on myocardial oxidative stress in patients with acute coronary syndromes undergoing percutaneous coronary intervention. Coron Artery Dis. 2008; 19:99-104.

[52] Gosmanov AR, Gosmanova EO, Dillard-Cannon E. Management of adult diabetic ketoacidosis. Diabetes Metab Syndr Obes. 2014; 7:255-64.

[53] Amiel SA, Sherwin RS, Simonson DC, Tamborlane WV. Effect of intensive insulin therapy on glycemic thresholds for counterregulatory hormone release. Diabetes. 1988; 37:901-7.

[54] Liamis G, Liberopoulos E, Barkas F, Elisaf M. Diabetes mellitus and electrolyte disorders. World J Clin Cases. 2014; 2:488-96.

[55] Dungan KM, Braithwaite SS, Preiser JC. Stress hyperglycaemia. Lancet. 2009; 373:1798-807.

[56] De Vries FEE, Gans SL, Solomkin JS, Allegranzi B, Egger M, Dellinger EP, Boermeester MA. Meta-analysis of lower perioperative blood glucose target levels for reduction of surgical-site infection. Br J Surg. 2017; 104:e95-105.

[57] Frisch A, Chandra P, Smiley D, Peng L, Rizzo M, Gatcliffe C, et al. Prevalence and clinical outcome of hyperglycemia in the perioperative period in noncardiac surgery. Diabetes Care. 2010; 33:1783-8.

[58] Kwon S, Thompson R, Dellinger P, Yanez D, Farrohki E, Flum D. Importance of perioperative glycemic control in general surgery: a report from the surgical care and outcomes assessment program. Ann Surg. 2013; 257:8-14.

[59] Van den Berghe G, Wouters P, Weekers F, Verwaest C, Bruyninckx F, Schetz $\mathrm{M}$, et al. Intensive insulin therapy in critically ill patients. $\mathrm{N}$ Engl J Med. 2001; 345:1359-67.

[60] D’Alessandro C, Leprince P, Golmard JL, Ouattara A, Aubert S, Pavie A, et al. Strict glycemic control reduces EuroSCORE expected mortality in diabetic patients undergoing myocardial revascularization. J Thorac Cardiovasc Surg. 2007; 134:29-37.

[61] Kirdemir P, Yildirim V, Kiris I, Gulmen S, Kuralay E, Ibrisim E, Ozal E. Does continuous insulin therapy reduce postoperative supraventricular tachycardia incidence after coronary artery bypass operations in diabetic patients? J Cardiothorac Vasc Anesth. 2008; 22:383-7.

[62] Kotagal M, Symons RG, Hirsch IB, Umpierrez GE, Dellinger EP, Farrokhi ET, et al. Perioperative hyperglycemia and risk of adverse 
events among patients with and without diabetes. Ann Surg. 2015; 261:97-103.

[63] Buehler L, Fayfman M, Alexopoulos AS, Zhao L, Farrokhi F, Weaver J, et al. The impact of hyperglycemia and obesity on hospitalization costs and clinical outcome in general surgery patients. J Diabetes Complications. 2015; 29:1177-82.

[64] Margonis GA, Amini N, Sasaki K, Kim Y, Merath K, Buettner S, et al. Perioperative hyperglycemia and postoperative outcomes in patients undergoing resection of colorectal liver metastases. J Gastrointest Surg. 2017; 21:228-37.

[65] Kremers HM, Schleck CD, Lewallen EA, Larson DR, Van Wijnen AJ, Lewallen DG. Diabetes mellitus and hyperglycemia and the risk of aseptic loosening in total joint arthroplasty. J Arthroplasty. 2017; 32:s251-3.

[66] Fisette A, Hassanain M, Metrakos P, Doi SA, Salman A, Schricker $\mathrm{T}$, et al. High-dose insulin therapy reduces postoperative liver dysfunction and complications in liver resection patients through reduced apoptosis and altered inflammation. J Clin Endocrinol Metab. 2012; 97:217-26.

[67] Hassanain M, Metrakos P, Fisette A, Doi SA, Schricker T, Lattermann R, et al. Randomized clinical trial of the impact of insulin therapy on liver function in patients undergoing major liver resection. Br J Surg. 2013; 100:610-8.

[68] Duncan AE, Abd-Elsayed A, Maheshwari A, Xu M, Soltesz E, Koch CG. Role of intraoperative and postoperative blood glucose concentrations in predicting outcomes after cardiac surgery. Anesthesiology. 2010; 112:860-71.

[69] Yoo S, Lee HJ, Lee H, Ryu HG. Association between perioperative hyperglycemia or glucose variability and postoperative acute kidney injury after liver transplantation: a retrospective observational study. Anesth Analg. 2017; 124:35-41.

[70] Krinsley JS. Glycemic variability: a strong independent predictor of mortality in critically ill patients. Crit Care Med. 2008; 36:3008-13.

[71] Egi M, Bellomo R, Stachowski E, French CJ, Hart G. Variability of blood glucose concentration and short-term mortality in critically ill patients. Anesthesiology. 2006; 105:244-52.

[72] Monnier L, Mas E, Ginet C, Michel F, Villon L, Cristol JP, Colette C. Activation of oxidative stress by acute glucose fluctuations compared with sustained chronic hyperglycemia in patients with type 2 diabetes. JAMA. 2006; 295:1681-7.

[73] Houlden R, Capes S, Clement M, Miller D. In-hospital management of diabetes. Can J Diabetes. 2013; 37:S77-81.

[74] Dhatariya K, Levy N, Kilvert A, Watson B, Cousins D, Flanagan D, et al. NHS diabetes guideline for the perioperative management of the adult patient with diabetes. Diabet Med. 2012; 29:420-33.

[75] Abdelmalak BB, Knittel J, Abdelmalak JB, Dalton JE, Christiansen E, Foss J, et al. Preoperative blood glucose concentrations and postoperative outcomes after elective non-cardiac surgery: an observational study. Br J Anaesth. 2014; 112:79-88.

[76] Noordzij PG, Boersma E, Schreiner F, Kertai MD, Feringa HH, Dunkelgrun $\mathrm{M}$, et al. Increased preoperative glucose levels are associated with perioperative mortality in patients undergoing noncardiac, nonvascular surgery. Eur J Endocrinol. 2007; 156:137-42.

[77] Abdelmalak B, Abdelmalak JB, Knittel J, Christiansen E, Mascha $\mathrm{E}$, Zimmerman R, et al. The prevalence of undiagnosed diabetes in non-cardiac surgery patients, an observational study. Can J Anaesth. 2010; 57:1058-64.
[78] Hatzakorzian R, Bui H, Carvalho G, Shan WL, Sidhu S, Schricker T. Fasting blood glucose levels in patients presenting for elective surgery. Nutrition. 2011; 27:298-301.

[79] Krinsley JS. Glycemic control, diabetic status, and mortality in a heterogeneous population of critically ill patients before and during the era of intensive glycemic management: six and one-half years experience at a university-affiliated community hospital. Semin Thorac Cardiovasc Surg. 2006; 18:317-25.

[80] Lauruschkat AH, Arnrich B, Albert AA, Walter JA, Amann B, Rosendahl UP, et al. Prevalence and risks of undiagnosed diabetes mellitus in patients undergoing coronary artery bypass grafting. Circulation. 2005; 112:2397-402.

[81] Koenig RJ, Peterson CM, Jones RL, Saudek C, Lehrman M, Cerami A. Correlation of glucose regulation and hemoglobin $\mathrm{A}_{\mathrm{Ic}}$ in diabetes mellitus. N Engl J Med. 1976; 295:417-20.

[82] Gustafsson UO, Thorell A, Soop M, Ljungqvist O, Nygren J. Haemoglobin Alc as a predictor of postoperative hyperglycaemia and complications after major colorectal surgery. Br J Surg. 2009; 96:1358-64.

[83] Goh SNS, Yeoh E, Tan KY. Impact of perioperative hypoglycemia in subjects with diabetes undergoing colorectal surgery. Int J Colorectal Dis. 2017; 32:209-14.

[84] Halkos ME, Puskas JD, Lattouf OM, Kilgo P, Kerendi F, Song HK, et al. Elevated preoperative hemoglobin Alc level is predictive of adverse events after coronary artery bypass surgery. J Thorac Cardiovasc Surg. 2008; 136:631-40.

[85] O'Sullivan CJ, Hynes N, Mahendran B, Andrews EJ, Avalos G, Tawfik S, et al. Haemoglobin Alc (HbAlC) in non-diabetic and diabetic vascular patients. Is $\mathrm{HbAlC}$ an independent risk factor and predictor of adverse outcome? Eur J Vasc Endovasc Surg. 2006; 32:188-97.

[86] Ljungqvist O, Nygren J, Thorell A. Insulin resistance and elective surgery. Surgery. 2000; 128:757-60.

[87] Thorell A, Nygren J, Ljungqvist O. Insulin resistance: a marker of surgical stress. Curr Opin Clin Nutr Metab Care. 1999; 2:69-78.

[88] National Guideline Centre (UK). Preoperative tests (update): routine preoperative tests for elective surgery. London: National Institute for Health and Care Excellence (UK); 2016.

[89] Bock M, Johansson T, Fritsch G, Flamm M, Hansbauer B, Mann E, Sönnichsen A. The impact of preoperative testing for blood glucose concentration and haemoglobin Alc on mortality, changes in management and complications in noncardiac elective surgery: a systematic review. Eur J Anaesthesiol. 2015; 32:152-9.

[90] Partridge H, Perkins B, Mathieu S, Nicholls A, Adeniji K. Clinical recommendations in the management of the patient with type 1 diabetes on insulin pump therapy in the perioperative period: a primer for the anaesthetist. Br J Anaesth. 2016; 116:18-26.

[91] Sudhakaran S, Surani SR. Guidelines for perioperative management of the diabetic patient. Surg Res Pract. 2015; 2015:284063. doi:10.1155/2015/284063.

[92] Marks JB. Perioperative management of diabetes. Am Fam Physician. 2003; 67:93-100.

[93] Schricker T, Lattermann R. Perioperative catabolism. Can J Anaesth. 2015; 62:182-93.

[94] Sato H, Lattermann R, Carvalho G, Sato T, Metrakos P, Hassanain $\mathrm{M}$, et al. Perioperative glucose and insulin administration while maintaining normoglycemia (GIN therapy) in patients undergoing major liver resection. Anesth Analg. 2010; 110:1711-8. 
[95] Carvalho G, Moore A, Qizilbash B, Lachapelle K, Schricker T. Maintenance of normoglycemia during cardiac surgery. Anesth Analg. 2004; 99:319-24.

[96] Carvalho G, Pelletier P, Albacker T, Lachapelle K, Joanisse DR, Hatzakorzian R, et al. Cardioprotective effects of glucose and insulin administration while maintaining normoglycemia (GIN therapy) in patients undergoing coronary artery bypass grafting. J Clin Endocrinol Metab. 2011; 96:1469-77.

[97] Albacker T, Carvalho G, Schricker T, Lachapelle K. High-dose insulin therapy attenuates systemic inflammatory response in coronary artery bypass grafting patients. Ann Thorac Surg. 2008; 86:20-7.

[98] Karon BS, Donato LJ, Larsen CM, Siebenaler LK, Wells AE, Wood-Wentz CM, et al. Accuracy of capillary and arterial whole blood glucose measurements using a glucose meter in patients under general anesthesia in the operating room. Anesthesiology. 2017; 127:466-74.

[99] Karon BS, Meeusen JW, Bryant SC. Impact of glucose meter error on glycemic variability and time in target range during glycemic control after cardiovascular surgery. J Diabetes Sci Technol. 2016; 10:336-42.
[100] Egi M, Bellomo R. Reducing glycemic variability in intensive care unit patients: a new therapeutic target? J Diabetes Sci Technol. 2009; 3:1302-8.

[101] Sato H, Hosojima M, Ishikawa T, Aoki K, Okamoto T, Saito A, Tsuchida M. Glucose variability based in continuous glucose monitoring assessment is associated with postoperative complications after cardiovascular surgery. Ann Thorac Cardiovasc Surg. 2017; 23:239-47.

[102] Gomez AM, Umpierrez GE. Continuous glucose monitoring in insulin-treated patients in non-ICU settings. J Diabetes Sci Technol. 2014; 8:930-6.

[103] Donatelli F, Vavassori A, Bonfanti S, Parrella P, Lorini L, Fumagalli R, Carli F. Epidural anesthesia and analgesia decrease the postoperative incidence of insulin resistance in preoperative insulin-resistant subjects only. Anesth Analg. 2007; 104:1587-93.

[104] Umpierrez GE, Smiley D, Zisman A, Prieto LM, Palacio A, Ceron $\mathrm{M}$, et al. Randomized study of basal-bolus insulin therapy in the inpatient management of patients with type 2 diabetes (RABBIT 2 trial). Diabetes Care. 2007; 30:2181-6. 